\title{
Secretory Capacity of Isolated Pancreatic Acinar Cells
}

\author{
MARALYN E. KAUFMAN AND RICHARD J. GRAND(28) \\ Department of Pediatrics, Harvard Medical School, and the Department of Medicine (Division of \\ Gastroenterology), the Children's Hospital Medical Center, Boston, Massachusetts, USA
}

\begin{abstract}
Summary
In order to characterize the secretory capacity of isolated acinar cells, the effects of various secretagogues on amylase release were studied in guinea pigs. The effect of carbachol on amylase secretion reached a maximal level after a 30-min incubation and was dose dependent. At $1^{-4} \mathrm{M}$, carbachol induced a $33 \%$ increase in amylase secretion over control values $(P<0.001)$; at $10^{-6} \mathrm{M}$, there was an $8 \%$ increase over control $(P<0.05)$; and, at $10^{-8} M$, there was no change in amylase secretion. Muscarinic blockade with equimolar concentrations of atropine completely blocked the expected carbachol-induced increase in amylase secretion after both 30- and 60-min incubations. The response to secretin was neither significantly different from that to carbachol nor dose dependent over the concentration range tested. After a 30-min incubation, secretin induced significant increases in amylase secretion of $23 \%, 19 \%$, and $23 \%$ at concentrations of $10^{-5} \mathrm{M}, 10^{-7} \mathrm{M}$, and $10^{-9} \mathrm{M}$, respectively. As with carbachol, the response to secretin was blocked by atropine. Secretion of amylase in response to cholecystokininpancreozymin octapeptide (CCK-PZ) was maximal after a 30min incubation and was dose dependent. CCK-PZ, at concentrations of $10^{-7} \mathrm{M}$ and $1^{-9} \mathrm{M}$, induced significant increases in amylase secretion of 18\% $(P<0.001)$ and $17 \%(P<0.001)$, respectively. At $10^{-11} \mathrm{M}, \mathrm{CCK} \cdot \mathrm{PZ}$ did not evoke a significant increase in amylase secretion. The CCK-PZ-induced increase in amylase secretion was significantly less than that observed with carbachol $(P<0.05)$, was not significantly different from that observed with secretin, and was not potentiated by the simultaneous exposure of the acinar cells to carbachol.

The present experiments demonstrate the secretory capacity of pancreatic acinar cells in vitro. The preparation is minimally contaminated with islet cells and therefore appears to be a useful model for the study of stimulus-secretion coupling in the pancreas.
\end{abstract}

\section{Speculation}

The characterization of the secretory capacity of isolated pancreatic acinar cells represents a valuable addition to the study of stimulus-secretion coupling in the pancreas. The preparation will be a useful model for the future elucidation of development of mechanisms of protein secretion from exocrine tissue.

Although mechanisms of secretion in the pancreas have been extensively studied in vivo and in vitro $(4,7,10,20,24)$, the acinar phase of this process has received little attention. When intact pancreas or pancreatic fragments or slices are utilized, the magnitude of secretion observed is a reflection of the release of acinar protein plus any previously secreted protein stored in the ductular system.

Although the preparation originally described by Amsterdam and Jamieson (2), and used extensively by Gardner et al. $(9,10)$, provides an ideal model system for studies of isolated acinar cells, pancreatic secretion in such cells has not been fully characterized. Cells prepared by this technique maintain the structural features found in intact tissue and demonstrate little if any damage when studied biochemically. In addition, the acinar cell preparation eliminates the "wash-out" and ductular components of the secretory process and allows identification of acinar cell responses alone. In order to investigate the secretory capacity of isolated pancreatic acinar cells, we have explored the effects of a variety of stimuli on amylase secretion in such cells. The results obtained in these studies are discussed with regard to the potential mechanisms involved in stimulus-secretion coupling in pancreatic acinar cells.

\section{MATERIALS AND METHODS}

Male Hartley strain albino guinea pigs were maintained at $22^{\circ}$ and fed standard chow. For the $48 \mathrm{hr}$ preceding each experiment, animals were allowed water ad libitum, and were otherwise fasted. After the 2-day fast, the animals were stunned and then exsanguinated by severing the aorta. The pancreas was immediately removed, trimmed of excess fat and connective tissue, and placed in a Krebs-Ringer bicarbonate solution equilibrated with $95 \%$ oxygen-5\% $\mathrm{CO}_{2}(\mathrm{pH} \mathrm{7.4)}$ and containing 14 $\mathrm{mM}$ glucose, soybean trypsin inhibitor $0.1 \mathrm{mg} / \mathrm{ml}$, bovine serum albumin $2.5 \mathrm{mg} / \mathrm{ml}, 0.1 \mathrm{mM}$ calcium, and $1.2 \mathrm{mM}$ magnesium (solution 1). These and subsequent procedures were modifications of the techniques described by Amsterdam and Jamieson (2) and by Gardner et al. (9). In some experiments, solution 1 also contained the following nutrients: $6 \mathrm{mM}$ pyruvate, $6 \mathrm{mM}$ fumarate, $6 \mathrm{mM}$ glutamate, $2.6 \mathrm{ml} / 1 \mathrm{MEM}$ amino acid $(50 \times)$, $9.7 \mathrm{ml} /$ liter MEM vitamin solution (100\% concentration), and $9.7 \mathrm{ml} /$ liter glutamate suspension $(200 \mathrm{mM})$.

Using a 25-gauge needle, the pancreas was injected at room temperature with $4.8 \mathrm{ml}$ of a digestion solution (solution 1) containing crude collagenase $0.75 \mathrm{mg} / \mathrm{ml}$ and hyaluronidase 1.5 $\mathrm{mg} / \mathrm{ml}$. This procedure distended the gland and thereby exposed the pancreatic lobules to enzymatic digestion. The distended gland and excess digestion solution were then equilibrated with $95 \%$ oxygen $-5 \% \mathrm{CO}_{2}$ and incubated at $37^{\circ}$ for $15 \mathrm{~min}$ with agitation at 130 oscillations/min in a Dubnoff shaking metabolic incubator.

Excess digestion solution was aspirated from the flask and the tissue was incubated twice for $5 \mathrm{~min}$ at $37^{\circ}$ in $8 \mathrm{ml}$ of a KrebsRinger bicarbonate solution without calcium or magnesium and containing $2 \mathrm{mM}$ EGTA. The tissue was oxygenated during each of these two and all subsequent incubations. The tissue was then washed twice with $8 \mathrm{ml}$ solution 1 to replenish the divalent cations. A second digestion solution (containing collagenase and hyaluronidase at concentrations of $1.25 \mathrm{mg} / \mathrm{ml}$ and $2.0 \mathrm{mg} / \mathrm{ml}$ solution 1, respectively), was added and the incubation continued for $45 \mathrm{~min}$ at $37^{\circ}$. Single cells were liberated by five passages 
through a Pasteur pipette and three passages through a 10-cc syringe with a 20-gauge needle. Duplicate aliquots (approximately $4 \mathrm{ml}$ ) of the cell suspension were then layered over 2.8 $\mathrm{ml}$ columns of Krebs-Ringer bicarbonate solution containing 1 $\mathrm{mM}$ calcium, $1.2 \mathrm{mM}$ magnesium, and $4 \%$ bovine serum albumin in conical centrifuge tubes and centrifuged at $50 \times \mathrm{g}$ for $5 \mathrm{~min}$. The supernatant was discarded, the cells were combined, and this procedure was repeated twice. The cells were then suspended in a Krebs-Ringer bicarbonate solution containing $1 \mathrm{mM}$ calcium, $1.2 \mathrm{mM}$ magnesium, $1 \%$ bovine serum albumin, and $5 \mathrm{mM}$ theophylline to yield a concentration of approximately $5 \times 10^{5}$ cells $/ \mathrm{ml}$. In some experiments, this solution also contained $10 \mathrm{mM}$ sodium acetate. Viability of these cells was demonstrated by their ability to exclude trypan blue.

One-milliliter portions of the cell suspension were transferred to test tubes, gassed with $95 \%$ oxygen-5\% $\mathrm{CO}_{2}$, and incubated in a metabolic shaker for $10 \mathrm{~min}$ at $37^{\circ}$ with agitation at 60 oscillations/min. After the 10 -min preincubation, blocking agents and/or agonists or their solvent control solutions were added to the cell suspension in volumes varying between 0.005 and $0.15 \mathrm{ml}$, and incubations were continued for 30 or $60 \mathrm{~min}$. The final concentrations of all pharmacologic additions are noted in the figure and table legends. At the end of the incubation period the cell suspensions were centrifuged at 1000 $\times g$ for $10 \mathrm{~min}$ at $4^{\circ}$. The supernatants were removed and frozen for subsequent determination of amylase activity. The cells remaining in the tubes were suspended in $1 \mathrm{ml} 0.02 \mathrm{M}$ potassium phosphate buffer ( $\mathrm{pH} 6.9$ ), sonicated, and frozen for subsequent determination of amylase activity.

Amylase was determined by the method of Bernfeld (3) modified for incubation at $30^{\circ}$, as previously described (11). With this method, $1 \mathrm{U}$ amylase is the amount of enzyme that liberates $1 \mathrm{mg}$ maltose in $3 \mathrm{~min}$ at $30^{\circ}$. Total amylase activity was determined by adding the amylase activities of the supernatant and cell suspension. The amylase activity in the supernatant was then expressed as a percentage of the total amylase activity. Any change in amylase activity in the supernatant produced by addition of blocking agents and/or agonists (referred to as amylase secretion) was expressed as a percentage of change compared with control values.

Statistical analyses of data were made using the one-tailed Student's $t$-test for unpaired samples. Values for $P>0.05$ were considered not significant (NS).

Male Hartley strain albino guinea pigs $(350-400 \mathrm{~g})$ were obtained from Charles River Laboratories, Inc., Wilmington, MA. CCK-PZ octapeptide was a gift from S. J. Luciana of The Squibb Institute for Medical Research, Princeton, NJ. Secretin was purchased from Schwarz/Mann, Division of Becton-Dickinson and Co., Orangeburg, NY. Chromatographically purified soybean trypsin inhibitor was purchased from Worthington Biochemical Corp., Freehold, NJ. Crude collagenase (Clostridium histolyticum EC 3.4 .4 .19 ), crude bovine testis hyaluronidase (EC 3.2.k.35), bovine serum albumin (fraction V), pyruvic acid, fumaric acid, and glutamic acid were purchased from Sigma Chemical Co., St. Louis, MO. MEM amino acids $(50 \times)$, Lglutamine $(200 \mathrm{mM})$, and MEM vitamin solution (100\% concentration) were purchased from Grand Island Biochemical Co., Grant Island, NY. All other reagents were of the highest grade commercially available.

\section{RESULTS}

In preliminary experiments, basal secretion was studied in order to characterize the random variation in amylase release in isolated pancreatic acinar cells incubated in vitro. The cell suspensions used for these and all subsequent studies contained approximately $5 \times 10^{5}$ cells $/ \mathrm{ml}$ with a total amylase level of 85 \pm 10 (mean $\pm \mathrm{SE}$ ) units $/ \mathrm{ml}$. On the basis of these data, basal amylase secretion greater than $10 \%$ of the total amylase activity identified damaged cells: in all subsequent experiments in which basal amylase secretion in control cells was greater than $10 \%$ results were discarded. The magnitude of the secretory response to stimulation rarely exceeded $50 \%$ above control values. Before stimulation, total amylase activity in different preparations varied very little.

Contamination of the acinar cell preparation by islet cells was minimal. The insulin content (radioimmunoassay performed by Dr. Kenneth Gabbay, Children's Hospital Medical Center, Boston) of whole pancreas prior to isolation of cells was 137 $\mu \mathrm{U} / \mathrm{mg}$ protein, whereas that of the isolated cell preparation was $15 \mu \mathrm{U} / \mathrm{mg}$ protein.

\section{CARBACHOL}

The effect of carbachol on amylase secretion from isolated pancreatic acinar cells after a 30-min incubation was dose dependent (Fig. 1). At concentrations of $10^{-4} \mathrm{M}$ and $10^{-6} \mathrm{M}$, carbachol induced a highly significant increase in amylase secretion, but at $10^{-8} \mathrm{M}$, there was no change in amylase secretion compared with control.

Because of previous data suggesting that metabolic substrates might improve the secretory activity of isolated pancreatic acinar cells, experiments were repeated using carbachol $\left(10^{-4} \mathrm{M}\right)$ as the secretagogue with various additives to incubation media (Table 1). The most significant carbachol-induced increase in

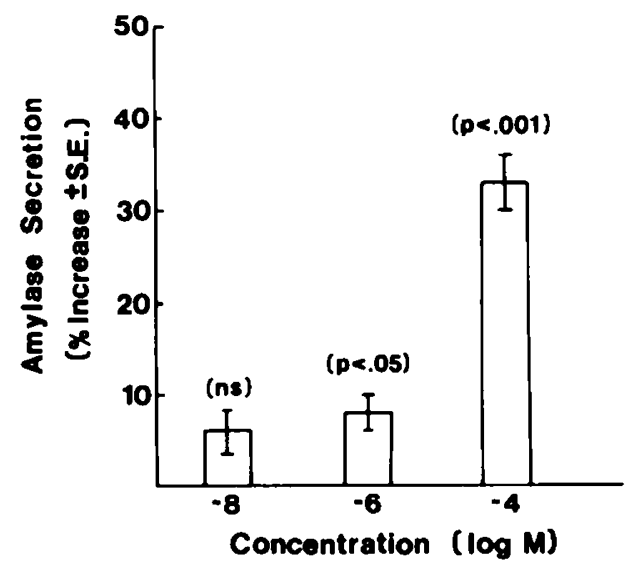

Fig. 1. Response of amylase secretion to graded doses of carbachol after a 30-min incubation. Amylase secretion expressed as percentage of increase over control. Bars correspond to the mean $\pm \mathrm{SE}$ of seven animals. Values for $\boldsymbol{P}$ denote statistical significance versus control.

Table 1. Effect of various additives on secretory activity of isolated acinar cells

\begin{tabular}{lc}
\hline \multicolumn{1}{c}{ Incubation solution } & $\begin{array}{c}\text { Carbachol-induced amy- } \\
\text { lase secretion }{ }^{1} \\
(\% \text { increase } \pm \mathrm{SE})\end{array}$ \\
\hline A. Without nutrients-without $\mathrm{NaAc}^{2}$ & $21 \pm 5(P<0.01)$ \\
B. With nutrients-without $\mathrm{NaAc}^{3}$ & $28 \pm 10(P<0.05)$ \\
C. Without nutrients-with $\mathrm{NaAc}^{4}$ & $27 \pm 8(P<0.05)$ \\
D. With nutrients-with $\mathrm{NaAc}^{5}$ & $2 \pm 11(\mathrm{NS})$ \\
\hline
\end{tabular}

${ }^{1}$ The concentration of carbachol was $10^{-4} \mathrm{M}$. Results are mean $\pm \mathrm{SE}$ of three animals and are expressed as percentage of increase over control. Values for $\boldsymbol{P}$ denote statistical significance versus control.

${ }^{2}$ Krebs-Ringer bicarbonate solution containing $1 \mathrm{mM}$ calcium, 1.2 $\mathrm{mM}$ magnesium, $1 \%$ bovine serum albumin, and $5 \mathrm{mM}$ theophylline.

${ }^{3}$ Same as Solution $A$, with addition of $6 \mathrm{mM}$ pyruvate, $6 \mathrm{mM}$ fumarate, $6 \mathrm{mM}$ glutamate, $2.6 \mathrm{ml}$ MEM amino acid $(50 \times) / \mathrm{liter}, 9.7 \mathrm{ml}$ MEM vitamin solution (100\% concentration)/liter, and $9.7 \mathrm{ml} \mathrm{L}$-glutamine suspension $(200 \mathrm{mM}) /$ liter.

${ }^{4}$ Same as solution $A$, with addition of $10 \mathrm{mM} \mathrm{NaAc}$.

${ }^{5}$ Combination of solutions $B$ and $C$. 
amylase secretion was seen when the cells were incubated in a Krebs-Ringer bicarbonate solution containing only calcium, magnesium, bovine serum albumin, and theophylline (Table 1, A). The addition of either nutrients or $\mathrm{NaAc}$ to the suspension medium did not facilitate carbachol-induced amylase secretion. Note that although the carbachol-induced increases in amylase secretion under conditions $B$ and $C$ are significantly different from control, they are not different from the increase in amylase secretion caused by carbachol in medium $1 \mathrm{~A}$. Carbachol did not induce any increase in amylase secretion in cells suspended in the medium containing both nutrients and $\mathrm{NaAc}$ (Table 1, D). The remainder of our experiments were performed using the optimal incubation medium $1 \mathrm{~A}$ (Table 1).

The effect of carbachol on amylase secretion as a function of time is shown in Figure 2. The increase in amylase secretion produced by carbachol after a $30-\mathrm{min}$ incubation appeared to be maximal since there was no further increase after a 60 -min incubation. Also, muscarinic blockade with an equimolar concentration of atropine completely prevented the increase in amylase secretion expected with carbachol at both 30 and 60 $\min$.

\section{SECRETIN}

Dose-response data for the effects of secretin on isolated pancreatic acinar cells are shown in Figure 3. At all of the concentrations studied, there was a significant secretin-induced increase in amylase secretion. The magnitude of this response did not change with increasing concentrations of secretin.

Because previous studies (9) suggested that theophylline might potentiate the action of secretin, effects of the combina-

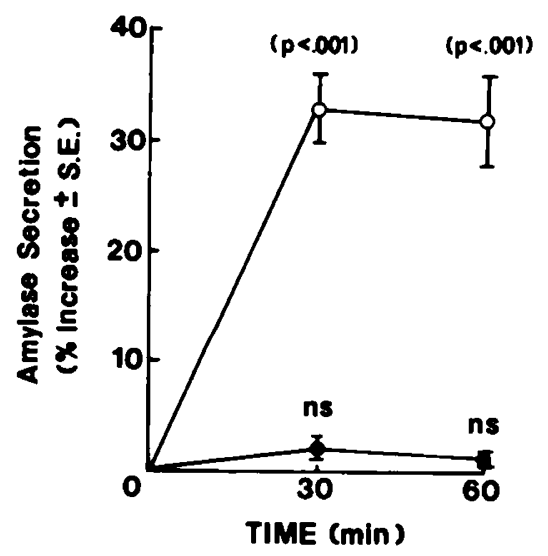

Fig. 2. Amylase secretion in the presence of $10^{-4} \mathrm{M}$ carbachol $(O)$ and $10^{-4} \mathrm{M}$ carbachol plus $10^{-4} \mathrm{M}$ atropine $(\bullet)$. Points correspond to the mean $\pm \mathrm{SE}$ of six animals. Values for $P$ denote statistical significance versus control.

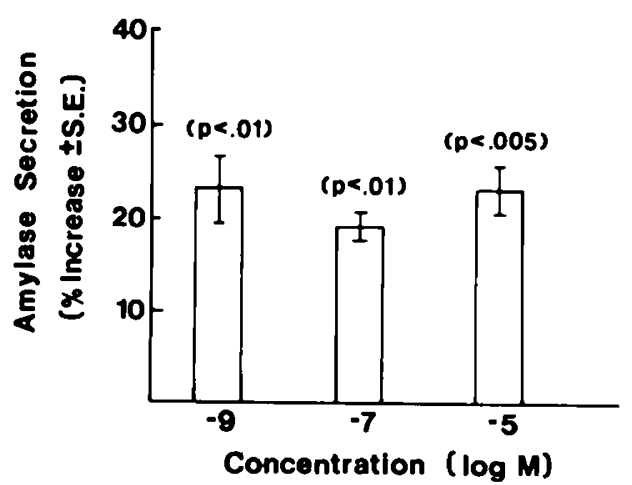

Fig. 3. Amylase secretion in response to secretin after a 30-min incubation. Amylase secretion expressed as percentage of increase over control. Bars correspond to mean $\pm \mathrm{SE}$ of four animals. Values for $P$ denote statistical significance versus control. tion of these agonists on amylase secretion were investigated. After a 30-min incubation (Table 2), secretin and theophylline each induced a significant increase in amylase secretion over control. Secretin plus theophylline induced an increase which was not significantly different from that obtained with secretin alone. Hence, at the concentrations studied, theophylline did not potentiate the effect of secretin on amylase secretion.

It is well known that atropine impairs secretin-stimulated enzyme secretion from pancreas in intact animals (12). Accordingly, the cellular effects of atropine and secretin on the isolated pancreatic acinar cell system were studied. At the concentrations investigated (Table 2), atropine eliminated the previously observed secretin-induced increase in amylase secretion.

\section{CCK-PZ}

Dose-response data for the effects of CCK-PZ on isolated pancreatic acinar cells are shown in Figure 4. CCK-PZ $\left(10^{-7} \mathrm{M}\right.$ and $\left.10^{-9} \mathrm{M}\right)$ caused significant increases in amylase secretion. No increase in amylase secretion was observed in acinar cells exposed to CCK-PZ at a concentration of $10^{-11} \mathrm{M}$. The response to $10^{-7} \mathrm{M}$ CCK-PZ observed after a $30-\mathrm{min}$ incubation was similar to that seen after a 60 -min incubation (Table 3 ).

The effects of CCK-PZ in combination with carbachol were examined in order to observe both hormonal and cholinergic stimulation of the pancreas (Table 3). After both 30- and 60min incubations in the presence of equimolar concentrations of $\mathrm{CCK}-\mathrm{PZ}$ and carbachol, amylase secretion was significantly increased over control values. After a 60 -min incubation, CCK$\mathrm{PZ}$ in combination with a lower dose of carbachol produced a similar increase in amylase secretion. These increases were not significantly different from those induced by CCK-PZ alone.

Table 2. Effects of secretin, theophylline, and atropine on amylase secretion

\begin{tabular}{lcl}
\hline Secretagogue (conc) & $\begin{array}{c}\text { Blocking agent } \\
\text { (conc) }\end{array}$ & $\begin{array}{l}\text { Amylase secretion }{ }^{1} \% \\
\text { increase } \pm \mathrm{SE}), 30 \mathrm{~min}\end{array}$ \\
\hline Secretin $\left(10^{-5} \mathrm{M}\right)$ & & $23 \pm 3(P<0.01)$ \\
Theophylline $\left(10^{-2} \mathrm{M}\right)$ & & $15 \pm 4(P<0.05)$ \\
$\begin{array}{c}\text { Secretin }\left(10^{-5} \mathrm{M}\right)+\text { the- } \\
\text { ophylline }\left(10^{-2} \mathrm{M}\right)\end{array}$ & $23 \pm 1(P<0.001)$ \\
Secretin $\left(10^{-5} \mathrm{M}\right)$ & $\begin{array}{c}\text { Atropine } \\
\left(10^{-5} \mathrm{M}\right)\end{array}$ & $7 \pm 2$ (NS) \\
\hline
\end{tabular}

${ }^{1}$ Results are mean $\pm \mathrm{SE}$ of five animals and are expressed as percentage of increase over control. Values for $P$ denote statistical significance versus control.

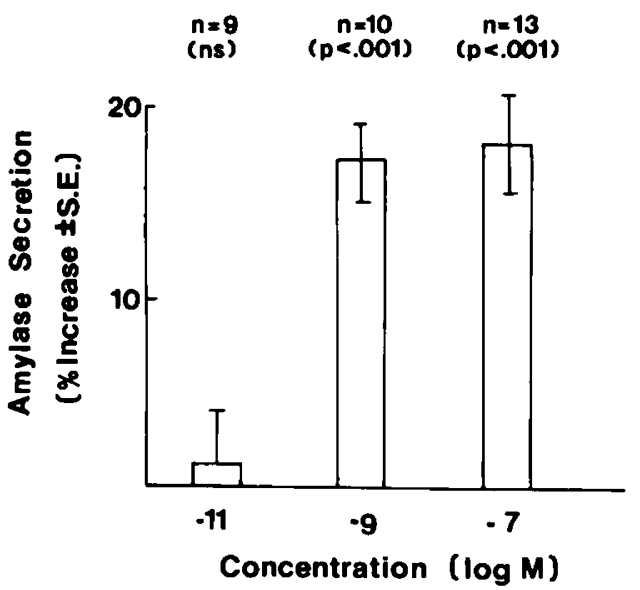

Fig. 4. Amylase secretion in response to graded doses of CCK-PZ after a 30-min incubation. Amylase secretion expressed as percentage of increase over control. Bars correspond to the mean $\pm S E$. $n$ : number of animals. Values for $P$ denote statistical significance versus control. 
Table 3. Effects of cholecystokinin-pancreozymin (CCK-PZ) with and without varied concentrations of carbachol on amylase secretion after 30-min and 60-min incubations

\begin{tabular}{|c|c|c|}
\hline \multirow[b]{2}{*}{ Secretagogue (conc) } & \multicolumn{2}{|c|}{$\begin{array}{c}\text { Amylase secretion }^{1} \text { (\% increase } \\
\pm \mathrm{SE} \text { ) }\end{array}$} \\
\hline & $30 \mathrm{~min}$ & $60 \mathrm{~min}$ \\
\hline CCK-PZ $\left(10^{-7} \mathrm{M}\right)$ & $\begin{array}{l}18 \pm 3 \\
\mathrm{n}=13 \\
P<0.001\end{array}$ & $\begin{array}{l}16 \pm 4 \\
\mathrm{n}=6 \\
P<0.02\end{array}$ \\
\hline $\begin{array}{l}\text { CCK-PZ }\left(10^{-7} \mathrm{M}\right)+\text { carbachol } \\
\quad\left(10^{-7} \mathrm{M}\right)\end{array}$ & $\begin{array}{l}17 \pm 4 \\
\mathrm{n}=4 \\
P<0.02\end{array}$ & $\begin{array}{l}17 \pm 4 \\
\mathrm{n}=5 \\
P<0.02\end{array}$ \\
\hline $\begin{array}{l}\text { CCK-PZ }\left(10^{-7} \mathrm{M}\right)+\text { carbachol } \\
\left(10^{-10} \mathrm{M}\right)\end{array}$ & & $\begin{array}{l}18 \pm 3 \\
\mathrm{n}=5 \\
P=<0.01\end{array}$ \\
\hline
\end{tabular}

${ }^{1}$ Results are mean \pm SE and are expressed as percentage of increase over control. $\mathrm{n}$ : number of animals. Values for $\boldsymbol{P}$ denote statistical significance versus control.

\section{DISCUSSION}

The present data demonstrate that isolated guinea pig acinar cells are responsive in vitro to both cholinergic and hormonal stimulation; indeed, carbachol, secretin, and CCK-PZ evoke significant increases in amylase secretion. The magnitude of the secretory response in isolated acinar cells is blunted in comparison to that obtained in intact animals, tissue slices, or fragments $(4,7,10,20,24)$, but the technique allows direct observations on a single cell population which cannot be obtained using other preparations. Explanations for the diminished responsiveness of the isolated acinar cells might be: 1) alteration of hormone receptors induced by the preparative techniques; 2 ) changes in reactivity of the secretory mechanism resulting from an interruption of cell-cell interactions; and 3) elimination of the "washout" burst of amylase secretion found in studies of tissue slices or fragments. Under conditions of the present experiments, only the acinar component of secretion was studied.

The carbachol-induced increase in amylase activity was dose dependent, reached a maximal level at $30 \mathrm{~min}$ after the start of incubation, and, as expected, was blocked by atropine (Fig. 1 and 2). The maximal rise in amylase secretion induced by secretin was not statistically different from that observed with carbachol. By contrast, the response to secretin was not dosedependent over the range of concentrations tested (Fig. 3); however, the quantity of secretin available was limited and therefore higher pharmacologic doses of this agent were not studied. As with carbachol (Fig. 2), the response to secretin was blocked by atropine (Table 3 ). This observation is in accord with data obtained in vivo (12) and suggests that the effects of secretin on the pancreatic acinar cell may be mediated by cholinergic receptors.

Maximal secretion of amylase in response to CCK-PZ occurred at $30 \mathrm{~min}$ after exposure to the hormone, was significantly less than that observed with carbachol $(P<0.05)$, was not significantly different from that observed with secretin, and was dose dependent over the concentration range tested (Table 3, Fig. 4). The effects of an optimal concentration of CCK-PZ were not potentiated by the simultaneous use of carbachol, thus confirming in vitro the findings obtained by Haymovits and Scheele (13) with caerulein and carbachol. In our experiments, the magnitude of the secretion stimulated by the agents studied was less than that in comparable experiments reported by Williams et al. (24) and Gardner et al. (10). However, these differences may be due to the longer preincubation time (60 min) used by those workers. In experiments with shorter preincubations, Kondo and Schulz (15) have reported values similar to those obtained in the present study.

The present experiments confirm and extend the observations of others on the secretory capacity of pancreatic acinar cells in vitro. In addition, these results and those in the literature provide further insight into the mechanisms involved in stimulussecretion coupling in these cells. It is well established that the effects of secretin on the exocrine pancreas are mediated by changes in the levels of intracellular cAMP $(1,5,8,9,20,21)$. Furthermore, Gardner et al. (9) have demonstrated secretininduced increases in levels of cAMP in isolated pancreatic acinar cells in the presence, but not in the absence, of $5 \mathrm{mM}$ theophylline. The present studies show significant amylase secretion in response to secretion stimulation, in media containing $5 \mathrm{mM}$ theophylline, but demonstrate no potentiation of the effect with high dose theophylline $\left(10^{-2} \mathrm{M}\right)$ (Table 2). One must therefore assume that in the presence of $5 \mathrm{mM}$ theophylline (the concentration contained in solution $1 \mathrm{~A}$, Table 1) the response of the acinar cells to secretin $\left(10^{-5} \mathrm{M}\right)$ is maximal.

Carbachol and CCK-PZ have been shown to increase amylase secretion in all pancreatic preparations studied $(2,7,10,15-20$, $22,23)$. In accord with these data, we also demonstrated carbachol- and CCK-PZ-induced increases in amylase secretion in isolated acinar cells. That these effects are not dependent upon cAMP is confirmed by the studies of Gardner et al. (9), who failed to demonstrate an increase in intracellular cAMP levels after exposure of pancreatic acinar cells to these agents. Similarly, perfusion of the pancreas with dibutyryl cAMP fails to stimulate amylase secretion (6). The actual intracellular mediators of secretory effects of carbachol and CCK-PZ are unknown. Available evidence suggests that intracellular calcium and possibly cGMP are involved (4), but the sequence of stimulus-secretion coupling under these conditions is unknown. Further studies of the time course of changes in calcium kinetics, cGMP levels, phosphodiesterases, and amylase secretion are necessary, and are currently in progress in this laboratory. On the basis of the present experiments, the isolated acinar cell preparation would appear to be a useful model for detailed studies of pancreatic function.

Note Added in Proof. Gardner and Jackson have recently published studies similar to those reported here (Gardner, J. D., and Jackson, M. J.: Regulation of amylase release from dispersed pancreatic acinar cells. J. Physiol. (Lond.), 270: 439 (1977)).

\section{REFERENCES AND NOTES}

1. Albano, J., Bhoola, K. D., and Harvey, R. F.: Intracellular messenger role of cyclic GMP in exocrine pancreas. Nature, 262: 404 (1976).

2. Amsterdam, A., and Jamieson, J. D.: Structural and functional characterization of isolated pancreatic exocrine cells. Proc. Nat. Acad. Sci. U. S. A., 69: 3028 (1972).

3. Bernfeld, P.: Amylases, $\alpha$ and $\beta$. In: S. P. Colowick and N. O. Kaplan: Methods in Enzymology, Vol. 8, p. 149 (Academic Press, New York, 1966)

4. Berridge, M. J.: Interactions of cyclic nucleotides and calcium in the control of cellular activity. In: P. Greengard and G. A. Robison: Advances in Cyclic Nucleotide Research, Vol. 6, p. 26 (Raven Press, New York, 1975).

5. Bhoola, K. D., and Lemon, M. J. C.: Studies on the activation of adenylate cyclase from the submaxillary gland and pancreas. J. Physiol., 232: 83P (1973).

6. Case, R. M., and Scratcherd, T.: The actions of dibutyryl cyclic adenosine $3^{\prime}, 5^{\prime}$-monophosphate and methyl xanthines on pancreatic exocrine secretion. J. Physiol., 223: 649 (1972).

7. Descholdt-Lanckman, M., Robberecht, P., DeNeef, P., Labrie, F., and Christophe, J.: In vitro interactions of gastrointestinal hormones on cyclic adenosine $3^{\prime}: 5^{\prime}$-monophosphate levels and amylase output in the rat pancreas. Gastroenterology, 68: 318 (1975).

8. Descholdt-Lanckman, M., Robberecht, P., DeNeef, P., Lammens, M., and Christophe, J.: In vitro action of bombesin and bombesin-like peptides on amylase secretion, calcium efflux, and adenylate cyclase activity in the rat pancreas. J. Clin. Invest., 58: 891 (1976).

9. Gardner, J. D., Conlon, T. P., and Adams, T. D.: Cyclic AMP on pancreatic acinar cells: effects of gastrointestinal hormones. Gastroenterology, 70:29 (1976).

10. Gardner, J. D., Conlon, T. P., Klaeveman, H. L., Adams, T. D., and Ondetti, M. A.: Action of cholcystokinin and cholinergic agents on calcium transport in isolated pancreatic acinar cells. J. Clin. Invest., 56: 366 1975).

11. Grand, R. J., and Gross, P. R.: Independent stimulation of secretion and 
protein synthesis in rat parotid gland. J. Biol. Chem., 244: 5608 (1969).

12. Grossman, M. I.: Nervous and hormonat regulation of pancreatic secretion In: A. V. S. deReuck, and M. P. Cameron: The Exocrine Pancreas, p. 208 (Little, Brown and Company, Boston, 1961).

13. Haymovits, A., and Scheele, G. A.: Cellular cyclic nucleotides and enzyme secretion in the pancreatic acinar cell. Proc. Nat. Acad. Sci. U. S. A., 73: 156 (1976).

14. Heisler, S., Fast, D., and Tenenhouse, A.: Role of $\mathrm{Ca}^{2+}$ and cyclic AMP in protein secretion from rat exocrine pancreas. Biochim. Biophys. Acta, 279 $561(1972)$

15. Kondo, S., and Schulz, I.: Calcium ion uptake in isolated pancreas cells induced by secretagogues. Biochim. Biophys. Acta, 419: 76 (1976).

16. Kulka, R. G., and Sternlicht, E.: Enzyme secretion in mouse pancreas mediated by adenosine- $3^{\prime}, 5^{\prime}$-cyclic phosphate and inhibited by adenosine 3'-phosphate. Proc. Nat. Acad. Sci. U. S. A., 61: 1123 (1968).

17. Lambert, M., Camus, J., and Christophe, J.: Pancreozymin and caerulein stimulate in vitro protein phosphorylation in the rat pancreas. Biochem. Biophys. Res. Commun., 52: 935 (1973).

18. Morisset, J. A., and Webster, P. D.: In vitro and in vivo effects of pancreozymin, urecholine and cyclic AMP on rat pancreas. Amer. J. Physiol., 230: 202 (1971).

19. Ridderstap, A. S., and Bonting, S. L.: Cyclic AMP and enzyme secretion by the isolated rabbit pancreas. Pflugers Arch. Ges. Physiol., 313: 62 (1969).

20. Robberecht, P., Descholdt-Lanckman, M., DeNeef, P., and Christophe, J.: Effects of somatostatin on pancreatic exocrine function: Interaction with

Copyright (c) 1978 International Pediatric Research Foundation, Inc. $0031-3998 / 78 / 1204-0288 \$ 02.00 / 0$ secretin. Biochem. Biophys. Res. Commun., 67: 315 (1975).

21. Rutten, W. J., DePont, J. J. H. H. M., and Bonting, S. L.: Adenylate cyclase in the rat pancreas, properties and stimulation by hormones. Biochim. Biophys. Acta, 274: 201 (1972).

22. Scheele, G., and Palade, G. E.: Studies on the guinea pig pancreas. J. Biol. Chem., 250: 2660 (1975).

23. Schreurs, V. V. A. M., Swarts, H. G. P., dePont, J. J. H. H. M., and Bonting, S. L.: Role of calcium in exocrine pancreatic secretion. II. Comparison of the effects of carbachol and the ionophore A-23187 on enzyme secretion and calcium movements in rabbit pancreas. Biochim. Biophys. Acta, 419: 320 (1976).

24. Williams, J. A., Cary, P., and Moffat, B.: Effects of ions on amylase release by dissociated pancreatic acinar cells. Amer. J. Physiol., 231: 1562 (1976).

25. The authors are indebted to Ms. Stephanie Ryan for technical assistance and to Drs. John A. Williams, Jerry D. Gardner, and Michael J. Jackson for valuable advice.

26. Dr. R. J. Grand is recipient of Academic Career Development Award 5-K07AM 44590 from the NIAMDD.

27. This research was supported by USPHS Research Grant AM-15423 from the NIAMDD.

28. Requests for reprints should be addressed to: R. J. Grand, M. D., Division of Gastroenterology, the Children's Hospital Medical Center, 300 Longwood Avenue, Boston, MA 02115 (USA)

29. Received for publication May $3,1977$.

30. Accepted for publication July 13, 1977. 